\title{
How Can Accreditation Bodies, Such as JACIE or FACT, Support Centres in Getting Qualified?
}

\author{
Riccardo Saccardi and Fermin Sanchez-Guijo
}

The FACT-JACIE accreditation system is based on a standard-driven process covering all the steps of HSC transplant activity, from donor selection to clinical care. Since the first approval of the First Edition of the Standards in 1998, over 360 HSCT programmes or facilities have been accredited at least once, most of them achieving subsequent re-accreditations (Snowden et al. 2017). The positive impact of the accreditation process in the EBMT Registry has been well established (Gratwohl et al. 2014). Starting with version 6.1, the standards include new items specifically developed for other cellular therapy products, with special reference to immune effector cells (IECs). This reflects the rapid evolution of the field of cellular therapy, primarily (but not exclusively) through the use of genetically modified cells, such as CAR-T cells. FACT-JACIE standards cover a wide range of important aspects that can be of use for centres that aim to be accredited in their countries to provide IEC therapy. Notably, FACT-JACIE accreditation itself is a key (or even a prerequisite) condition in some countries for approval by health authorities to provide commercial CAR-T cell therapy and is also valued by pharmaceutical companies (both those developing clinical trials and those manufacturing commercial products), which also inspect the cell therapy programmes and facilities established at each centre (Hayden et al. 2021). Interest in applying for FACT-JACIE accreditation that includes IEC therapeutic programmes is clearly increasing, from four applications in 2017 to 36 applications approved in 2019. The standards do not cover the manufacturing of such cells but include the chain of responsibilities when the product is

\footnotetext{
R. Saccardi

Cell Therapy and Transfusion Medicine Unit, Careggi University Hospital, Florence, Italy e-mail: riccardo.saccardi@aouc.unifi.it

F. Sanchez-Guijo $(\triangle)$

Cell Therapy Area and Hematology Department, University Hospital of Salamanca,

Salamanca, Spain

Department of Medicine, University of Salamanca, Salamanca, Spain

e-mail: ferminsg@usal.es 
provided by a third party (Maus and Nikiforow 2017). In any case, all the steps in the process in which the centre is involved (e.g., patient or donor evaluations, cell collection, cell reception, and storage) are covered by the standards, including the appropriate agreements with the internal partners, including the pharmacy department. In addition, from a clinical perspective, IECs may require special safety monitoring systems due to the high frequency of acute adverse events related to the massive immunological reaction against the tumour. Although examples and explanations are found in the standard manual, here, the special importance of identifying and managing cytokine release syndrome (CRS) should be emphasized, and the standards focus not on specific therapeutic algorithms but on ensuring that medical and nursing teams are sufficiently trained in the early detection of this and other potential complications (e.g., neurological complications). They also pay attention to the full-time availability within the institution and its pharmacy of the necessary medication to address complications and the capacitation and involvement of Intensive Care and Neurology Department professionals to provide urgent care if needed. Forthcoming cellular therapy products, currently under investigation, will show a wider range of risk profiles, therefore requiring product-specific risk assessment and consequent adaptation of the clinical procedures for different classes of products. The FACT-JACIE standards will continue to adapt to these future needs to assist centres in their achievement of optimal clinical outcomes.

\section{Key Points}

- FACT-JACIE standards have helped accredited centres improve their HSCT clinical outcomes for more than 20 years.

- Standards have been adapted to cover immune effector cell (IEC) therapy and are a key element in demonstrating optimal quality and performance for seeking accreditation by both National Health Authorities and the pharmaceutical companies involved.

- The IEC product chain of responsibilities, agreements with all involved partners, and full coverage of related adverse events are among the key elements of IEC-related standards.

\section{References}

Gratwohl A, Brand R, McGrath E, et al. Use of the quality management system "JACIE" and outcome after hematopoietic stem cell transplantation. Haematologica. 2014;99:908-15.

Hayden PJ, Roddie C, Bader P, Basak GW, Bonig H, Bonini C, et al. Management of adults and children receiving CAR T-cell therapy: 2021 best practice recommendations of the European Society for Blood and Marrow Transplantation (EBMT) and the Joint Accreditation Committee of ISCT and EBMT (JACIE) and the European Haematology Association (EHA). Ann Oncol. 2021;S0923-7534(21):04876-6. https://doi.org/10.1016/j.annonc.2021.12.003. Online ahead of print.

Maus MV, Nikiforow S. The why, what, and how of the new FACT standards for immune effector cells. J Immunother Cancer. 2017;5:36.

Snowden JA, McGrath E, Duarte RF, et al. JACIE accreditation for blood and marrow transplantation: past, present and future directions of an international model for healthcare quality improvement. Bone Marrow Transplant. 2017;52:1367-71. 
Open Access This chapter is licensed under the terms of the Creative Commons Attribution 4.0 International License (http://creativecommons.org/licenses/by/4.0/), which permits use, sharing, adaptation, distribution and reproduction in any medium or format, as long as you give appropriate credit to the original author(s) and the source, provide a link to the Creative Commons license and indicate if changes were made.

The images or other third party material in this chapter are included in the chapter's Creative Commons license, unless indicated otherwise in a credit line to the material. If material is not included in the chapter's Creative Commons license and your intended use is not permitted by statutory regulation or exceeds the permitted use, you will need to obtain permission directly from the copyright holder.

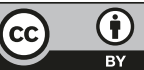

